\title{
Influence of Tillage Method on Management of Amaranthus Species in Soybean
}

\author{
Jaime A. Farmer, Kevin W. Bradley, Bryan G. Young, Lawrence E. Steckel, William G. Johnson, \\ Jason K. Norsworthy, Vince M. Davis, and Mark M. Loux*
}

A field study was conducted in 2014 and 2015 in Arkansas, Illinois, Indiana, Ohio, Tennessee, Wisconsin, and Missouri to determine the effects of tillage system and herbicide program on season-long emergence of Amaranthus species in glufosinate-resistant soybean. The tillage systems evaluated were deep tillage (fall moldboard plow followed by $(\mathrm{fb})$ one pass with a field cultivator in the spring), conventional tillage (fall chisel plow $\mathrm{fb}$ one pass with a field cultivator in the spring), minimum tillage (one pass of a vertical tillage tool in the spring), and no-tillage (PRE application of paraquat). Each tillage system also received one of two herbicide programs; PRE application of flumioxazin $\left(0.09 \mathrm{~kg} \mathrm{ai} \mathrm{ha}^{-1}\right) \mathrm{fb}$ a POST application of glufosinate $\left(0.59 \mathrm{~kg}\right.$ ai ha $\left.{ }^{-1}\right)$ plus $S$-metolachlor $\left(1.39 \mathrm{~kg}\right.$ ai ha $\left.{ }^{-1}\right)$, or POST-only applications of glufosinate $\left(0.59 \mathrm{~kg} \mathrm{ha}^{-1}\right)$. The deep tillage system resulted in a 62,67 , and $73 \%$ reduction in Amaranthus emergence when compared to the conventional, minimum, and no-tillage systems, respectively. The residual herbicide program also resulted in an $87 \%$ reduction in Amaranthus species emergence compared to the POST-only program. The deep tillage system, combined with the residual program, resulted in a 97\% reduction in Amaranthus species emergence when compared to the minimum tillage system combined with the POST-only program, which had the highest Amaranthus emergence. Soil cores taken prior to planting and herbicide application revealed that only $28 \%$ of the Amaranthus seed in the deep tillage system was placed within the top $5-\mathrm{cm}$ of the soil profile compared to 79,81 , and $77 \%$ in the conventional, minimum, and no-tillage systems. Overall, the use of deep tillage with a residual herbicide program provided the greatest reduction in Amaranthus species emergence, thus providing a useful tool in managing herbicide-resistant Amaranthus species where appropriate.

Nomenclature: Flumioxazin; glufosinate; metolachlor; paraquat; Amaranthus; soybean, Glycine max (L.) Merr.

Key words: moldboard plow, vertical tillage, seedbank, soil-applied residual.

En 2014 y 2015, se realizó un estudio de campo en Arkansas, Illinois, Indiana, Ohio, Tennessee, Wisconsin, y Missouri para determinar los efectos del sistema de labranza y el programa de herbicidas sobre la emergencia de especies de Amaranthus a lo largo de la temporada de crecimiento en soja resistente a glufosinate. Los sistemas de labranza evaluados fueron labranza profunda (arado de vertedera en el otoño seguido por ( $\mathrm{fb}$ ) un pase de cultivador de campo en la primavera), labranza convencional (arado de cincel en el otońo seguido de un pase de cultivador de campo en la primavera), labranza mínima (un pase de una herramienta de labranza vertical en la primavera), y cero labranza (aplicación PRE de paraquat). Cada sistema de labranza también recibió uno de dos programas de herbicidas; aplicación PRE de flumioxazin $\left(0.09 \mathrm{~kg}^{\mathrm{ai}} \mathrm{ha} \mathrm{H}^{-1}\right) \mathrm{fb}$ glufosinate POST $\left(0.59 \mathrm{~kg}\right.$ ai ha $\left.{ }^{-1}\right)$ más $S$-metolachlor $\left(1.39 \mathrm{~kg}\right.$ ai ha $\left.{ }^{-1}\right)$, o sólo aplicaciones POST de glufosinate $(0.59 \mathrm{~kg}$ $\left.\mathrm{ha}^{-1}\right)$. El sistema de labranza profunda resultó en una reducción de 62, 67, y 73\% en la emergencia de Amaranthus cuando se comparó con los sistemas de labranza convencional, mínima, y cero, respectivamente. El programa con un herbicida residual también resultó en una reducción de $87 \%$ en la emergencia de especies Amaranthus al compararse con el programa de sólo herbicidas POST. El sistema de labranza profunda, combinado con el programa residual, resultó en una reducción de $97 \%$ en la emergencia de especies de Amaranthus cuando se comparó con el sistema de labranza mínima combinado con el programa de sólo herbicidas POST, el cual tuvo la mayor emergencia de Amaranthus. Muestras de suelo tomadas antes de la siembra y la aplicación de herbicidas revelaron que en el sistema de labranza profunda solamente $28 \%$ de las semillas de Amaranthus

\footnotetext{
DOI: 10.1614/WT-D-16-00061.1

*First and second authors: Graduate Student, Associate Professor, Division of Plant Science, 108 Waters Hall, University of Missouri, Columbia, MO 65211; Third and fifth authors: Associate Professor, Professor, Department of Botany and Plant Pathology, Purdue University, West Lafayette, IN 47907; Fourth author: Professor, Department of Plant Sciences, University of Tennessee, Knoxville, TN 37996; Sixth author: Professor, Department of Crop, Soil, and Environmental Sciences, University of Arkansas, Fayetteville, AR 72704; Seventh author: former Assistant Professor, Department of Agronomy, University of Wisconsin, Madison, WI 53705; Eighth author: Professor, Department of Horticulture and Crop Science, Ohio State University, Columbus, OH 43210. Corresponding author's E-mail: bradleyke@missouri.edu
} 
fueron localizadas en los $5 \mathrm{~cm}$ de suelo superiores del perfil del suelo comparado con 79, 81, y 77\% en los sistemas de labranza convencional, mínima, y cero. En general, el uso de labranza profunda con el programa de herbicida residual brindó la mayor reducción en la emergencia de especies de Amaranthus, lo que provee una herramienta útil para el manejo de especies de Amaranthus resistentes a herbicidas cuando sea apropiado.

The adoption of conservation-tillage practices and glyphosate-resistant (GR) crops over the last several decades has led to an increased reliance on herbicides as one of the primary methods of weed control (Culpepper et al. 2000; DeVore et al. 2013; Krausz et al. 1993; Young 2006). Glyphosate-resistant crops have been rapidly adopted since their release in 1996 and have enabled producers to simplify weed management by providing control of a broad spectrum of common weeds with little or no injury to the crop (Fernandez-Cornejo and Mcbride 2002). In 1997, only $17 \%$ of US soybean hectares were planted with herbicide-resistant varieties (Fernandex-Cornejo and Wechsler 2015). By 2015, 94\% of soybean hectares were planted with herbicide-resistant varieties, with the vast majority of those being GR (FernandexCornejo and Wechsler 2015). The continuous use of glyphosate on millions of hectares has led to the selection of GR weed biotypes around the world (Heap 2016). The United States currently has 14 GR weed species, including 3 Amaranthus species: Palmer amaranth (Amaranthus palmeri S. Wats.), spiny amaranth (Amaranthus spinosus L.) and waterhemp (Amaranthus rudis Sauer). Among the 14 GR weeds, waterhemp and Palmer amaranth are consistently ranked as two of the most common and persistent weeds in southern and midwestern United States crops, especially in soybean (Beckie 2006; Bradley 2013; Heap 2016; Legleiter and Johnson 2013; Schultz et al. 2015b; Webster and Nichols 2012). The evolution of glyphosate resistance in weeds like Palmer amaranth and waterhemp has increased production costs in soybean and complicated weed management dramatically (Legleiter et al. 2009; Mueller et al. 2005).

Soybean yield losses of $43 \%$ have been reported after $10 \mathrm{wk}$ of interference by waterhemp at densities of 89 to 362 plants $\mathrm{m}^{-2}$ (Hager et al. 2002). Palmer amaranth at a density of 8 plants per meter of row that emerged with soybean reduced yields by $79 \%$ (Bensch et al. 2003). Currently, Palmer amaranth populations with resistance to six different herbicide modes of action have been confirmed: 5-enolpyruvyl-shikimate3-phosphate (EPSP) synthase-inhibitors, microtubuleinhibitors, photosystem II-inhibitors, acetolactate synthase (ALS)-inhibitors, protoporphyrinogen oxidase (PPO)-inhibitors, and 4-hydroxyphenylpyruvate dioxygenase (HPPD)-inhibitors (Heap 2016). In addition, waterhemp with resistance to six different herbicide modes of action has been reported in the United States: synthetic auxins and EPSP-, ALS-, photosystem II-, PPO-, and HPPD-inhibitors (Heap 2016).

The increase in the occurrence of multipleherbicide resistance in Amaranthus species and other weeds illustrates the need for producers to diversify their weed management practices (Bradley 2013; Norsworthy et al. 2012). Cultural control practices such as tillage can significantly impact weed populations (Norsworthy et al. 2012). Tillage has a large impact on the vertical distribution of weed seed in the soil profile and on weed emergence (Cousens and Moss 1990; Roberts 1963; Starica et al. 1990). Tillage implements that provide deep inversion of the soil place weed seed low enough in the soil profile to prevent successful germination and emergence (DeVore et al. 2013). Shaw et al. (2012) defined inversion tillage as tillage that flips over a layer of soil (often 15 to $30 \mathrm{~cm}$ ), burying surface residues in the process. Moldboard plowing, a type of inversion tillage, not only kills plants but also can bury $>95 \%$ of weed seeds at a depth from which most cannot emerge (Douglas and Peltzer 2004; Morris et al. 2010). Swanton et al. (2000) found that moldboard plowing resulted in $63 \%$ of weed seeds being concentrated at a depth of 10 to $15 \mathrm{~cm}$. In contrast, Clements et al. (1996) and Pareja et al. (1985) both found that no-tillage systems result in the largest concentration of weed seed being contained in the uppermost layers of soil. However, soil type has also been shown to affect the vertical distribution of weed seed caused by tillage (Swanton et al. 2000). Diversified integrated weed management strategies, including the incorporation of cultural practices such as tillage, narrow row spacing, and increased seeding densities, are among the best management practices currently recommended for the prevention, mitigation, and management of herbicide-resistant weed species (Beckie 2006; Norsworthy et al. 2012; Schultz et al. 2015a). 
The initial effectiveness and simplicity of the GR cropping system led many producers to rely solely on POST herbicide applications for weed control in soybean (Powles 2008; Young 2006). As a result, Palmer amaranth and waterhemp have evolved resistance to herbicides that act at many different sites of action, but, at the current time, neither of these species has evolved resistance to glufosinate (Heap 2016). If used appropriately, glufosinate remains an effective POST option for the control of Amaranthus species in glufosinate-resistant soybean (Heap 2016; Norsworthy et al. 2008). However, it has been shown that repeated POST-only herbicide applications can lead to the selection of herbicideresistant weed biotypes (Bradley 2013; Powles 2008). The use of residual herbicide applications, PRE and POST, has been shown to reduce weed densities while also reducing the likelihood of herbicide resistance (Beckie 2006; Bradley 2013; Legleiter et al. 2009; Schultz et al. 2015a).

The effect of tillage systems and residual herbicide programs on the control of GR Amaranthus species in glufosinate-resistant soybean has not been researched extensively over a broad range of geographies and soil types. The objectives of this research were to 1) determine the effect of four tillage systems (deep tillage, conventional tillage, minimum tillage, and no tillage), with and without a residual herbicide program, on season-long emergence of Amaranthus species in glufosinate-resistant soybean, and to 2) determine the effect of these four tillage systems on the vertical distribution of Amaranthus seed in the soil profile.

\section{Materials and Methods}

A field study was conducted in 2014 and 2015 at sites in Randolph County, Missouri; Boone County, Missouri; Washington County, Arkansas; St. Claire County, Illinois; Tippecanoe County, Indiana; Clark County, Ohio; Madison County, Tennessee; and Columbia County, Wisconsin (Table 1). Glufosinate-resistant soybean varieties of an appropriate maturity group were seeded at 321,000 to 432,000 seeds $\mathrm{ha}^{-1}$ in rows spaced 76 to $91 \mathrm{~cm}$ apart, depending upon location. Specific site information, such as previous crop production history, crop information, and soil type, is provided in Table 1. Monthly rainfall totals are presented in Table 2.

Treatments were arranged as a split-plot design with four replications, where tillage system was the main plot and herbicide program was the subplot, arranged in a randomized complete block design. Four tillage regimes were evaluated: 1) a fall tillage pass of a moldboard plow followed by a pass with a field cultivator in the spring, referred to as the deep-tillage treatment; 2) a fall pass with a chisel plow followed by a pass with a field cultivator in the spring, referred to as the conventional-tillage treatment; 3) a single pass of a vertical tillage tool in the spring, referred to as the minimum-tillage treatment; and 4) a no-tillage treatment that received a burndown herbicide treatment of paraquat $(0.84 \mathrm{~kg}$ $\left.\mathrm{ha}^{-1}\right)$ near the time of the spring tillage treatments. Dates of major field operations for each site are provided in Table 1. Each tillage treatment received one of two herbicide programs: 1) a PRE application of flumioxazin $\left(0.09 \mathrm{~kg} \mathrm{ha}^{-1}\right)$ followed by a POST application of glufosinate $\left(0.59 \mathrm{~kg} \mathrm{ha}^{-1}\right)$ plus $S$-metolachlor $\left(1.39 \mathrm{~kg} \mathrm{ha}^{-1}\right)$, referred to as the residual herbicide program, or 2) POST-only applications of glufosinate $\left(0.59 \mathrm{~kg} \mathrm{ha}^{-1}\right)$, referred to as the POST-only herbicide program. The specific herbicide formulations utilized are listed in Table 3. All herbicide treatments were applied with a $\mathrm{CO}_{2}$ pressurized backpack sprayer calibrated to deliver $140 \mathrm{~L} \mathrm{ha}^{-1}$. Treatments were applied at a constant speed of $5 \mathrm{~km} \mathrm{hr}^{-1}$. PRE treatments were applied at or just prior to planting. POST application for the residual herbicide program was applied $21 \mathrm{~d}$ after planting, and the first POST application for the POST-only herbicide program was applied approximately $14 \mathrm{~d}$ after planting.

Field Densities. Amaranthus species emergence was monitored every $14 \mathrm{~d}$ from planting up to the R6 soybean stage or senescence by counting all plants within two $1-\mathrm{m}^{2}$ quadrats between the center two rows of soybean. The location of each quadrat was permanently marked to ensure counts occurred in the same area for the duration of the experiment. Immediately after each weed count was completed, the entire area was treated with glufosinate $\left(0.59 \mathrm{~kg} \mathrm{ha}^{-1}\right)$ and then monitored for surviving weeds.

Vertical Seed Distribution. Vertical distribution of Amaranthus seed in the soil profile was determined by taking six 2.5 by $25 \mathrm{~cm}$ soil cores randomly from each plot utilizing 2.9-cm diameter soil recovery probes (AMS Inc., American Falls, ID). Soil probes were fitted with 2.5 by $30.5 \mathrm{~cm}$ acetate sleeves 
Table 1. Site characteristics for field trials conducted in 2014 and $2015 .^{a}$

\begin{tabular}{|c|c|c|c|c|c|c|c|c|c|c|}
\hline \multirow[b]{2}{*}{ Test site } & \multirow[b]{2}{*}{ Year } & \multicolumn{4}{|c|}{ Soil properties } & \multicolumn{2}{|c|}{ Tillage dates } & \multirow[b]{2}{*}{ Soybean variety } & \multirow[b]{2}{*}{ Plant population } & \multirow{2}{*}{$\begin{array}{c}\text { Planting } \\
\text { date }\end{array}$} \\
\hline & & Texture & $\mathrm{OM}$ & $\mathrm{pH}$ & $\overline{\mathrm{CEC}}$ & Fall $^{b}$ & Spring & & & \\
\hline & & & $\%$ & & & & & & seeds $\mathrm{ha}^{-1}$ & \\
\hline \multirow[t]{2}{*}{$\mathrm{AR}^{\mathrm{c}}$} & 2014 & silt loam & 1.8 & 5.8 & 11.7 & $10 / 18 / 13$ & $6 / 4 / 14$ & Pioneer $^{\circledR}$ 95L01 & 388,000 & $6 / 4 / 14$ \\
\hline & 2015 & silt loam & 1.8 & 5.8 & 11.7 & $9 / 30 / 14$ & $6 / 26 / 15$ & Credenz ${ }^{\circledR}$ LL4748 & 321,000 & $5 / 26 / 15$ \\
\hline IL $^{\mathrm{d}}$ & 2014 & silt loam & 3.0 & 6.1 & 12.0 & $10 / 28 / 13$ & $5 / 28 / 14$ & Pioneer ${ }^{\circledR}$ P43T41L & 346,000 & $5 / 28 / 14$ \\
\hline $\mathrm{IN}^{\mathrm{e}}$ & 2015 & silt loam & 2.3 & 6.5 & 14.3 & $3 / 24 / 15$ & $5 / 14 / 15$ & Beck's 298NL & 345,000 & $5 / 14 / 15$ \\
\hline \multirow[t]{2}{*}{$\mathrm{MO} 1^{\mathrm{f}}$} & 2014 & silt loam & 2.1 & 6.4 & 11.0 & $10 / 28 / 13$ & $5 / 6 / 14$ & MorSoy LL3759N & 432,000 & $5 / 7 / 14$ \\
\hline & 2015 & silt loam & 2.0 & 6.3 & 10.5 & $4 / 1 / 15$ & $6 / 11 / 15$ & MorSoy LL3759N & 432,000 & $6 / 12 / 15$ \\
\hline \multirow[t]{2}{*}{$\mathrm{MO} 2^{\mathrm{g}}$} & 2014 & silt loam & 1.9 & 6.3 & 9.80 & $10 / 27 / 13$ & $5 / 6 / 14$ & MorSoy LL3759N & 432,000 & $5 / 21 / 14$ \\
\hline & 2015 & silt loam & 1.6 & 5.9 & 9.10 & $4 / 17 / 15$ & $5 / 12 / 15$ & MorSoy LL3759N & 432,000 & $5 / 13 / 15$ \\
\hline \multirow[t]{2}{*}{$\mathrm{WI}^{\mathrm{j}}$} & 2014 & silt loam & 2.9 & 7.1 & - & - & - & Tracy's 2513 LL & 346,000 & $5 / 22 / 14$ \\
\hline & 2015 & silt loam & 3.1 & 7.1 & - & - & - & Tracy's 2513 LL & 346,000 & $5 / 21 / 15$ \\
\hline
\end{tabular}

a Abbreviations: CEC, cation exchange capacity (meq per $100 \mathrm{~g}$ soil); OM, organic matter.

${ }^{\mathrm{b}}$ Due to excessive soil moisture at and following harvest, some fall-tillage operations were not able to be completed until the following spring.

${ }^{\mathrm{c}}$ Fayetteville, Arkansas. Arkansas Agriculture Research and Extension Center, University of Arkansas $\left(36.092996^{\circ} \mathrm{N}, 94.173423^{\circ} \mathrm{W}\right)$. Site has been in small-plot research with conventional tillage for the past $50 \mathrm{yr}$.

${ }^{\mathrm{d}}$ Belleville, Illinois. Belleville Research Center, Southern Illinois University (38.521476 $\left.\mathrm{N}, 89.845294^{\circ} \mathrm{W}\right)$. Small-plot research for more than 7 yr. No deep tillage for at least $30 \mathrm{yr}$.

${ }^{\mathrm{e}}$ Lafayette, Indiana. Throckmorton Purdue Agricultural Center, Purdue University $\left(40.271114^{\circ} \mathrm{N}, 86.881163^{\circ} \mathrm{W}\right)$. Research plots with conventional tillage for at least $9 \mathrm{yr}$.

${ }^{\mathrm{f}}$ Columbia, Missouri. Bradford Research and Extension Center, University of Missouri (38.898432 $\left.{ }^{\circ} \mathrm{N}, 92.216371^{\circ} \mathrm{W}\right) . \mathrm{Small}^{-\mathrm{plot}}$ research for $50 \mathrm{yr}$. Conservation agriculture at least $12 \mathrm{yr}$.

${ }^{\mathrm{g}}$ Moberly, Missouri. Resistant Waterhemp Research Site, University of Missouri (39.302782 ${ }^{\circ}$, 92.369678 $\left.{ }^{\circ} \mathrm{W}\right)$. Continuous soybean production for at least $12 \mathrm{yr}$. Conservation agriculture the past 15 years. Confirmed presence of waterhemp populations resistant to glyphosate and protoporphyrinogen oxidase- and acetolactate synthase-inhibiting herbicides.

${ }^{\mathrm{h}}$ South Charleston, Ohio. Western Agricultural Research Station, Ohio State University $\left(39.8593^{\circ} \mathrm{N}, 83.66971^{\circ} \mathrm{W}\right)$. Small-plot $^{\circ}$ research more than 20 yr. Conventional tillage annually.

${ }^{\mathrm{i}}$ Jackson, Tennessee. West Tennessee AgResearch and Education Center, University of Tennessee $\left(35.624655^{\circ} \mathrm{N}, 88.845096^{\circ} \mathrm{W}\right) . \mathrm{No}$ deep tillage for at least $30 \mathrm{yr}$. Mostly no-till practices.

${ }^{\mathrm{j}}$ Arlington, Wisconsin. Arlington Agricultural Research Station, University of Wisconsin (43.307943N, 89.350072 W). Agronomy research for more than $10 \mathrm{yr}$. Chisel plowing $(25 \mathrm{~cm})$ occurred once, two years prior to initiation of this study.

(AMS Inc.). Soil cores were taken after the spring tillage operations prior to planting and herbicide application. Soil cores from all sites were packaged with dry ice and shipped overnight to the University of Missouri-Columbia, where they were stored at $-9 \mathrm{C}$ until processing.

Each soil core was divided into following segments by soil profile depth, with zero representing the soil surface: 0 to $1 \mathrm{~cm}, 1$ to $5 \mathrm{~cm}, 5$ to $10 \mathrm{~cm}, 10$ to $15 \mathrm{~cm}, 15$ to $20 \mathrm{~cm}$, and 20 to $25 \mathrm{~cm}$. Each segment was placed as a topsoil layer in an individual 8 by
6 by $6 \mathrm{~cm}$ insert cell in a 28 by $56 \mathrm{~cm}$ greenhouse flat (Hummert International ${ }^{\mathrm{TM}}$, Earth City, MO) that had previously been three-quarters filled with commercial potting medium (Premier Tech Horticulture, Quakertown, PA). Plants were maintained in a greenhouse at 25 to $30 \mathrm{C}$, watered and fertilized as needed, and provided with artificial light from metal halide lamps $\left(600 \mu \mathrm{mol}\right.$ photon $\left.\mathrm{m}^{-2} \mathrm{~s}^{-1}\right)$ simulating a 16-h photoperiod. Seedling emergence was monitored over a 3-mo period. Emerged weed seedlings were counted and identified to species every 
Table 2. Monthly rainfall (mm) from April through October in 2014 and 2015 at all trial locations. The 30-yr monthly rainfall averages are provided for comparison. ${ }^{a}$

\begin{tabular}{|c|c|c|c|c|c|c|c|c|}
\hline \multirow[b]{3}{*}{ Site } & \multirow[b]{3}{*}{ Year } & \multicolumn{7}{|c|}{ Monthly rainfall } \\
\hline & & \multicolumn{7}{|c|}{$\mathrm{mm}$} \\
\hline & & Apr. & May & Jun. & Jul. & Aug. & Sep. & Oct. \\
\hline \multirow[t]{3}{*}{$\mathrm{AR}^{\mathrm{b}}$} & 2014 & 87 & 137 & 113 & 35 & 66 & 114 & 166 \\
\hline & 2015 & 81 & 169 & 175 & 269 & 68 & 47 & 58 \\
\hline & $30-y r$ avg $^{j}$ & 109 & 132 & 121 & 82 & 77 & 116 & 104 \\
\hline \multirow[t]{3}{*}{$\mathrm{IL}^{\mathrm{c}}$} & 2014 & 165 & 45 & 129 & 34 & 176 & 95 & 108 \\
\hline & 2015 & 91 & 211 & 243 & 99 & 108 & 68 & 24 \\
\hline & $30-y r$ avg & 98 & 124 & 108 & 103 & 84 & 83 & 87 \\
\hline \multirow{3}{*}{$\mathrm{IN}^{\mathrm{d}}$} & 2014 & 95 & 111 & 89 & 83 & 112 & 68 & 159 \\
\hline & 2015 & 102 & 109 & 211 & 177 & 45 & 73 & 43 \\
\hline & $30-y r$ avg & 87 & 118 & 116 & 104 & 100 & 71 & 69 \\
\hline \multirow[t]{3}{*}{$\mathrm{MO}^{\mathrm{e}}$} & 2014 & 210 & 78 & 129 & 37 & 75 & 156 & 259 \\
\hline & 2015 & 84 & 144 & 192 & 213 & 80 & 29 & 27 \\
\hline & $30-y r$ avg & 114 & 138 & 132 & 115 & 114 & 109 & 85 \\
\hline \multirow[t]{3}{*}{$\mathrm{MO}^{\mathrm{f}}$} & 2014 & 156 & 64 & 141 & 92 & 120 & 64 & 203 \\
\hline & 2015 & 65 & 119 & 299 & 223 & 73 & 20 & 43 \\
\hline & $30-y r$ avg & 104 & 131 & 130 & 122 & 106 & 110 & 84 \\
\hline \multirow[t]{3}{*}{$\mathrm{OH}^{\mathrm{g}}$} & 2014 & 137 & 110 & 165 & 100 & 83 & 32 & 37 \\
\hline & 2015 & 122 & 52 & 223 & 132 & 73 & 35 & 69 \\
\hline & $30-y r$ avg & 91 & 115 & 109 & 104 & 79 & 67 & 71 \\
\hline \multirow[t]{3}{*}{$\mathrm{TN}^{\mathrm{h}}$} & 2014 & 118 & 107 & 278 & 93 & 151 & 185 & 135 \\
\hline & 2015 & 152 & 126 & 136 & 118 & 111 & 90 & 70 \\
\hline & $30-y r$ avg & 120 & 141 & 126 & 122 & 78 & 89 & 101 \\
\hline \multirow[t]{3}{*}{$\mathrm{WI}^{\mathrm{i}}$} & 2014 & 164 & 71 & 238 & 48 & 95 & 45 & 70 \\
\hline & 2015 & 162 & 112 & 80 & 80 & 110 & 145 & 50 \\
\hline & $30-y r$ avg & 88.9 & 94 & 119 & 106 & 99 & 90 & 65 \\
\hline
\end{tabular}

a Abbreviations: avg, average.

b Fayetteville, Arkansas. Arkansas Agriculture Research and Extension Center, University of Arkansas (36.092996 N, 94.173423W). Site has been in small-plot research with conventional tillage for the past $50 \mathrm{yr}$.

${ }^{\mathrm{c}}$ Belleville, Illinois. Belleville Research Center, Southern Illinois University (38.521476 $\left.{ }^{\circ} \mathrm{N}, 89.845294^{\circ} \mathrm{W}\right)$. Small-plot research for more than 7 yr. No deep tillage for at least $30 \mathrm{yr}$.

${ }^{\mathrm{d}}$ Lafayette, Indiana. Throckmorton Purdue Agricultural Center, Purdue University $\left(40.271114^{\circ} \mathrm{N}, 86.881163^{\circ} \mathrm{W}\right)$. Research plots with conventional tillage for at least $9 \mathrm{yr}$.

${ }^{\text {e }}$ Columbia, Missouri. Bradford Research and Extension Center, University of Missouri (38.898432 $\left.{ }^{\circ} \mathrm{N}, 92.216371^{\circ} \mathrm{W}\right) . \mathrm{Small}^{-\mathrm{plot}}$ research for $50 \mathrm{yr}$. Conservation agriculture at least $12 \mathrm{yr}$.

${ }^{\mathrm{f}}$ Moberly, Missouri. Resistant Waterhemp Research Site, University of Missouri (39.302782 N, 92.369678W). Continuous soybean production for at least $12 \mathrm{yr}$. Conservation agriculture the past 15 years. Confirmed presence of waterhemp populations resistant to glyphosate and protoporphyrinogen oxidase-and acetolactate synthase-inhibiting herbicides.

g South Charleston, Ohio. Western Agricultural Research Station, Ohio State University (39.8593 $\left.\mathrm{N}, 83.66971^{\circ} \mathrm{W}\right)$. Small-plot research more than 20 yr. Conventional tillage annually.

${ }^{\mathrm{h}}$ Jackson, Tennessee. West Tennessee AgResearch and Education Center, University of Tennessee $\left(35.624655^{\circ} \mathrm{N}, 88.845096^{\circ} \mathrm{W}\right)$. No deep tillage for at least $30 \mathrm{yr}$. Mostly no-till practices.

${ }^{\mathrm{i}}$ Arlington, Wisconsin. Arlington Agricultural Research Station, University of Wisconsin $\left(43.307943^{\circ} \mathrm{N}, 89.350072^{\circ} \mathrm{W}\right)$. Agronomy research for more than $10 \mathrm{yr}$. Chisel plowing $(25 \mathrm{~cm})$ occurred once, two years prior to initiation of this study.

j Thirty-year averages (1982 to 2011) obtained from the National Climatic Data Center (2016).

$14 \mathrm{~d}$, then removed from the flats after counting. After 3 mo of monitoring in the greenhouse, the flats were removed and stored in the dark at $-9 \mathrm{C}$ for 3 mo of cold stratification. After cold treatment, flats were returned to the greenhouse and the soil in each cell was stirred by hand. Flats were monitored for weed 
Table 3. Sources of materials used in the experiments.

\begin{tabular}{lllcll}
\hline Herbicide & Trade name & Formulation $^{\text {a }}$ & Rate & Manufacturer & Address \\
\hline & & & $\mathrm{kg} \mathrm{ai} \mathrm{ha}^{-1}$ & & \\
Paraquat & Gramoxone Inteon $^{\circledR}$ & $2.0 \mathrm{SL}$ & 0.84 & Syngenta & Greensboro, NC \\
Flumioxazin & Valor $^{\circledR}$ & $51 \mathrm{WDG}$ & 0.09 & Valent USA & Walnut Creek, CA \\
S-metolachlor & Dual II Magnum $^{\circledR}$ & $7.64 \mathrm{EC}$ & 1.39 & Syngenta & Greensboro, NC \\
Glufosinate & Liberty $^{\circledR}$ & $280 \mathrm{SL}$ & 0.59 & Bayer CropScience & Research Triangle Park, NC \\
Ammonium sulfate & N-Pak $^{\circledR}$ AMS & $3.4 \mathrm{~L}$ & 2.9 & Winfield Solutions & St. Paul, MN \\
\hline
\end{tabular}

${ }^{\text {a }}$ Abbreviations: EC, emulsifiable concentrate; L, liquid; SL, soluble (liquid) concentrate; WDG, water-dispersible granule.

emergence for an additional 2 mo using the same photoperiod and temperature as before.

To ensure that the density of Amaranthus was adequate to compare treatments, field count data were only included in the statistical analysis if cumulative Amaranthus densities were greater than 300 plants per trial (12 of 16 site-years), and vertical distribution data were only included in the statistical analysis if Amaranthus densities were greater than 32 plants per trial (5 of 14 site-years; no cores were taken from the Ohio location). Amaranthus species density data from the field and vertical distribution data from the soil cores were analyzed separately using the PROC GLIMMIX procedure in SAS ${ }^{\circledR}$ version 9.4 (SAS Institute Inc., Cary, NC). Count data were transformed using a negative binomial function to satisfy Pearson's chi-square. Data were back-transformed for presentation. Replicate, tillage system, and herbicide program were considered fixed effects for the field count data. Replicate and tillage system were considered fixed effects for the soil core data. Siteyear combinations were analyzed as if they were random samples taken from the same environment, and site-years with adequate weed densities were combined for analysis (Blouin et al. 2011; Carmer et al. 1989). Individual treatment differences were separated using Fisher's protected LSD at $P \leq 0.05$. Significant differences were present in the field between tillage systems $(P<0.0001$; Figure 1$)$, herbicide programs $(P<0.0001)$, and tillage system herbicide program combinations $(P=0.04$; Figure 2). Significant differences were also present in the greenhouse studies between tillage system and soil profile depth $(P<0.0001$; Figure 3$)$. In Indiana, only two tillage systems were evaluated: conventional tillage and no tillage. Data from Indiana were analyzed separately using the same procedure that was used for the other sites. Significant differences were noted in the field studies in Indiana between tillage systems $(P<0.0068)$ and herbicide programs $(P<0.0001)$, but not between tillage system - herbicide program combinations $(P=0.7133$; data not shown). No significant differences were found between tillage system and soil profile depth for the soil cores taken from Indiana $(P=0.2061$; data not shown).

\section{Results and Discussion}

The deep-tillage system resulted in a $62 \%, 67 \%$, and $73 \%$ reduction in Amaranthus emergence compared with the conventional-, minimum-, and no-tillage systems, respectively, when averaged over all sites except Indiana (Figure 1). The conventional-tillage system resulted in a $28 \%$ reduction in Amaranthus species emergence compared with the no-tillage system, but emergence was similar in the minimum- and no-tillage

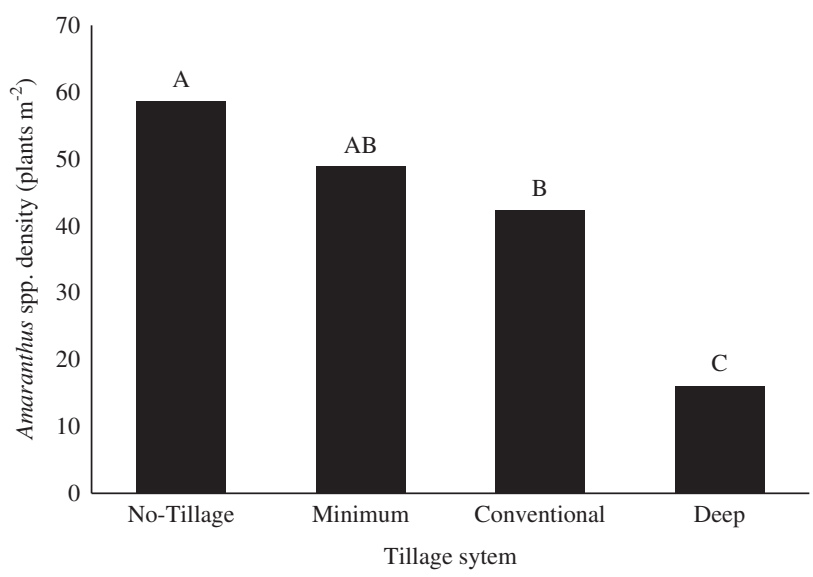

Figure 1. Influence of tillage method on Amaranthus species emergence across 10 site-years in Arkansas, Illinois, Missouri, Ohio, and Tennessee. Bars with the same letter are not different, LSD (0.05). 


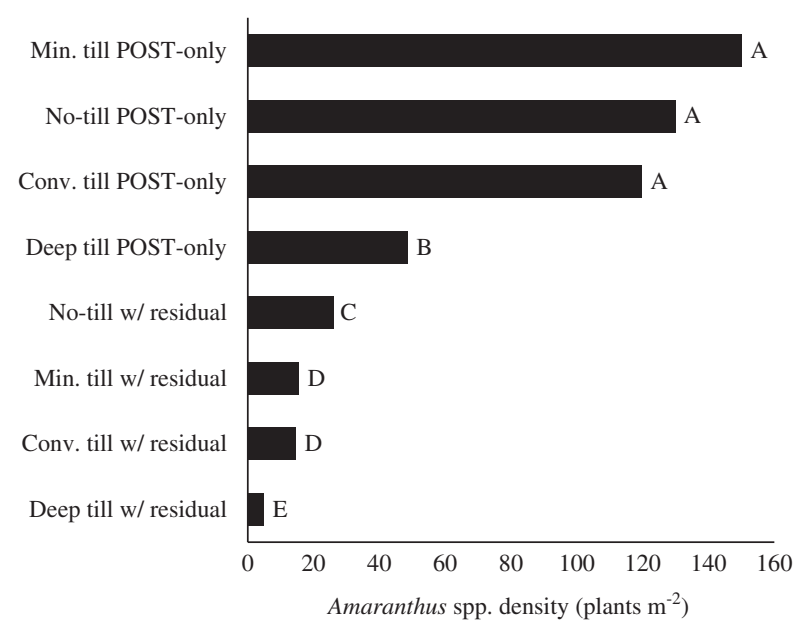

Figure 2. Influence of tillage treatment and herbicide program on Amaranthus species emergence in the field across 10 site-years in Arkansas, Illinois, Missouri, Ohio, and Tennessee. Min. till: minimum tillage; Conv. till: conventional tillage. Bars followed by the same letter are not different, LSD (0.05).

systems. Across both years in the experiment conducted in Indiana, there was a significant difference between the conventional- and no-tillage systems. In Indiana the conventional-tillage system resulted in a $64 \%$ reduction in emergence compared with the no-tillage system when averaged over all years, with 22 and 60 emerged plants $\mathrm{m}^{-2}$, respectively. The reason for the difference in results between Indiana and the other sites with regard to the relative effectiveness of the conventional and no-tillage systems is not readily apparent. Previous research utilizing similar treatments found that tillage systems that utilize a chisel plow (conventional treatment in this study) resulted in the majority of weed seed remaining high in the soil profile, similar to no tillage (Ball 1992; Clements et al. 1996; Pareja et al. 1985; Yenish et al. 1992). A reduction in Amaranthus species emergence as a result of deep tillage was also observed in a study in Arkansas comparing effects of deep-tillage and no-tillage treatments on Palmer amaranth emergence (DeVore et al. 2013). DeVore et al. (2013) found that deep tillage in an early soybean production system reduced Palmer amaranth emergence by $97 \%$ compared with no tillage, while deep tillage in a full-season soybean production system reduced Palmer amaranth emergence by $70 \%$ compared with no tillage. The level of Palmer amaranth reduction reported by $\mathrm{DeV}$ ore et al. is similar to the 73\% reduction in Amaranthus species emergence observed in this multi-state study (Figure 1). In another study with Palmer amaranth in Arkansas, Bell et al. (2015) found that $14 \mathrm{~d}$ after planting soybean in a deep-tillage treatment, Palmer amaranth densities were reduced by $94 \%$ to $95 \%$ in one year and $73 \%$ to $87 \%$ in another. Similar results have also been observed in Iowa, where moldboard and chisel plow treatments each decreased waterhemp emergence 4-fold compared with the no-tillage treatments (Leon and Owen 2006). The reduction in Amaranthus species emergence in deep- and conventional-tillage systems compared with no-tillage systems can be explained by the less favorable conditions for germination and seedling establishment for small-seeded weeds like Amaranthus when the seeds are buried deeper in the soil profile (Felix and Owen 1999; Hoffman et al. 1998; Webster et al. 1998; Yenish et al. 1992).

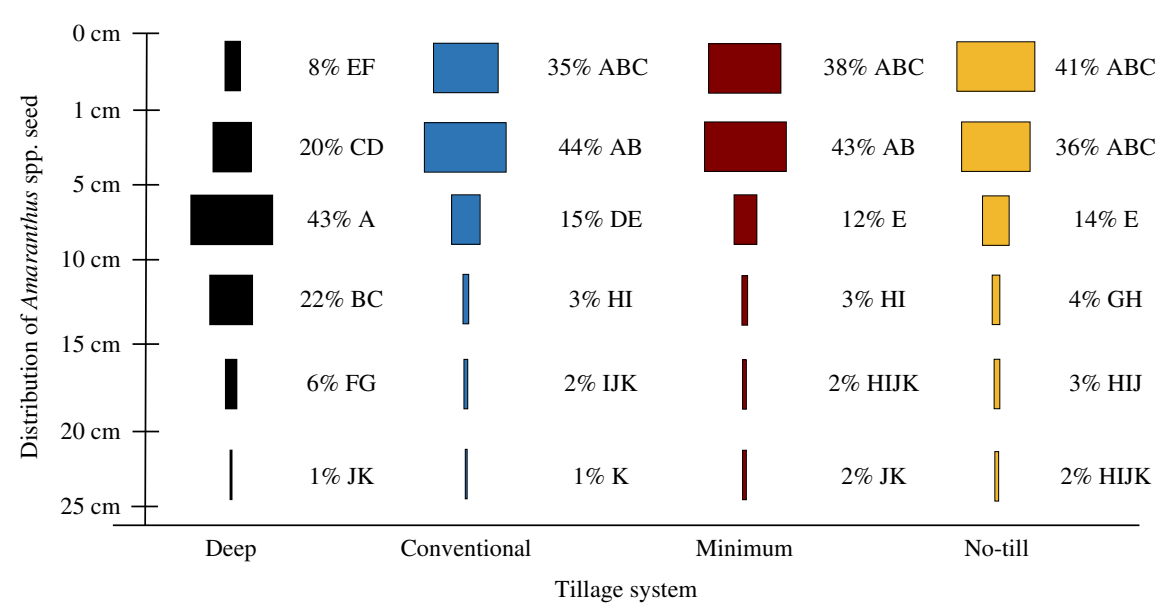

Figure 3. Influence of tillage method on the vertical distribution of Amaranthus species seeds in the soil profile. Results combined across the Missouri and Illinois sites. Each bar proportionally represents the average number of Amaranthus species that emerged from each soil core segment. Percentages followed by the same letter are not different, LSD (0.05). 
The residual herbicide program resulted in an 87\% reduction in Amaranthus species emergence compared with the POST-only program, when averaged over all except the Indiana sites, with 13 and 103 plants $\mathrm{m}^{-2}$, respectively. For the Indiana sites, the residual program resulted in a $98 \%$ reduction in emergence compared with the POST-only program, with 5 and 232 plants $\mathrm{m}^{-2}$ emerged, respectively. These results are similar to those reported by Schultz et al. (2015a), where a PRE fb POST with residual program had greater waterhemp density reduction (99\%) than two-pass POST-only applications of glufosinate $(72 \%)$ when compared to the non-treated control. Similar results have been observed across 4 site-years in Missouri in a study of herbicide programs in glufosinate-resistant soybean, where a residual program resulted in $93 \%$ control of waterhemp while two-pass POST-only program using glufosinate resulted in only $74 \%$ control (Craigmyle et al. 2013). In a study with GR waterhemp in Missouri, Legleiter et al. (2009) observed $97 \%$ and $98 \%$ GR waterhemp density reductions with residual herbicide programs, but less than $40 \%$ reduction with POST-only programs. Use of PRE herbicide applications of metolachlor plus metribuzin have also been shown to provide much higher economic returns than POST-only applications of glyphosate when GR weeds are present (Legleiter et al. 2009). These results support the recommendation to plant into fields that are weed-free and to keep them weed-free by utilizing residual herbicide applications before and/or after planting (Norsworthy et al. 2012), thus reducing the selection pressure for resistance to POST-only herbicides (Neve et al. 2003; Neve et al. 2011).

We observed an interaction between tillage system and herbicide program at all sites except the Indiana sites. The lowest emergence of Amaranthus species occurred with the combination of deep tillage and residual herbicide program (Figure 2). The combination of any tillage system with residual herbicides resulted in less Amaranthus emergence than the combination of any tillage system and the POSTonly herbicide program. There were no differences in Amaranthus species emergence among the conventional-, minimum-, and no-tillage systems where the POST-only herbicide program was used. The deep-tillage system in combination with the residual herbicide program resulted in a $97 \%$ reduction in Amaranthus species emergence compared with the minimum-tillage system combined with the POSTonly program, which resulted in the highest Amaranthus species emergence. Similar results were observed in an Arkansas study with an application of flumioxazin plus pyroxasulfone (3-[[5-(difluoromethoxy)-1-methyl-3-(trifluoromethyl)pyrazol-4-yl] methylsulfonyl]-5,5-dimethyl-4H-1,2-oxazole) applied PRE in combination with deep tillage (Bell et al. 2015). This combination resulted in $>98 \%$ Palmer amaranth control in both years of the study, and the authors concluded that deep tillage resulted in fewer Palmer amaranth plants present at the times of the POST herbicide applications (Bell et al. 2015). DeVore et al. (2013) concluded that adding a residual herbicide program to a deep-tillage early soybean production system would further reduce Palmer amaranth emergence, providing even greater control. The results of this research support this conclusion, as the deep-tillage system with the addition of a residual herbicide program provided the greatest reduction of Amaranthus species emergence across the major soybean-producing area in the United States (Figure 2).

Vertical Distribution of Amaranthus Seed. The conventional-, minimum-, and no-tillage systems resulted in similar Amaranthus species emergence from all soil depths (Figure 3). These results were also observed in a separate analysis across both years in Indiana in a comparison of the conventional and no-tillage systems $(P=0.2061$, data not shown). The deep-tillage system resulted in lower Amaranthus species emergence at the 0 to $1 \mathrm{~cm}, 5$ to $10 \mathrm{~cm}, 10$ to $15 \mathrm{~cm}$, and 15 to $20 \mathrm{~cm}$ depths compared with the other tillage systems. Seventy-two percent of the Amaranthus seeds in the deep-tillage system were located deeper than $5 \mathrm{~cm}$. These results are similar to those reported by Nichols et al. (2015), who utilized previous tillage research (Dorado et al. 1999; Mohler 1993) to predict that moldboard plowing would place the majority of seeds within the 5 to $15 \mathrm{~cm}$ soil profile range. Swanton et al. (2000) also reported that moldboard plowing resulted in less uniform vertical weed seed distribution in locations with sandy soils, but that $63 \%$ of the seeds were concentrated at depths of 10 to $15 \mathrm{~cm}$. The results from this study indicate that $28 \%$ of the Amaranthus seeds were placed in the top $5 \mathrm{~cm}$ of the soil profile by deep tillage. In contrast, $79 \%, 81 \%$, and $77 \%$ of the Amaranthus seed in the conventional-, minimum-, and no-tillage systems was located in the top $5 \mathrm{~cm}$ of 
the soil profile, respectively. These results are comparable to other studies, conducted across multiple soil types, that found that the majority of weed seed was located in the top $5 \mathrm{~cm}$ of the soil after conventional-, minimum-, and no-tillage treatments (Clements et al. 1996; Pareja et al. 1985; Swanton et al. 2000; Yenish et al. 1992). For example, Swanton et al. (2000) reported that $90 \%$ of the weed seedbank was concentrated in the top $5 \mathrm{~cm}$ of soil in a no-tillage system.

Based on the results of this research, deep-tillage systems utilizing a one-time inversion tillage implement, such as a moldboard plow, provide the greatest reduction in Amaranthus species emergence when compared with conventional-, minimum-, and no-tillage systems. However, deep-tillage systems are prone to increased soil erosion as well and can incur higher fuel and labor costs (Logan et al. 1987). Reducing tillage intensity through conservationtillage practices has been shown to reduce soil erosion and water runoff (Baumhardt and Lascano 1996; Reeves 1997) and increase soil organic matter, soil water-holding capacity, the quantity and diversity of soil organisms, and water infiltration (Bruce et al. 1992; Heisler 1998; Kemper and Derpsch 1981; Reeves 1997; Truman et al. 2003). Therefore, producers will need to weigh all of the potential risks, costs, and benefits before making a decision on either system. The results from this research also illustrate the effectiveness of a residual herbicide program when used in either tillage system. The incorporation of a residual herbicide, particularly a PRE herbicide prior to soybean planting, has been shown to provide better control and density reduction of Amaranthus species, as well as greater economic benefit, than POST-only programs (Legleiter et al. 2009; Schultz et al. 2015a). The combination of a residual herbicide program and a deep-tillage system provided the greatest reduction in Amaranthus species emergence throughout the season. These results support the recommendation to combine effective cultural practices with residual herbicide programs; using both together has been shown to be more effective than utilizing any one management technique alone (Norsworthy et al. 2012; Schultz et al. 2015a). As herbicide-resistant Amaranthus species become more prevalent throughout US soybean production systems, integrating cultural practices such as tillage, where appropriate, with residual herbicide programs that utilize multiple, effective sites of action can provide substantial reductions in herbicide-resistant Amaranthus species in soybean.

\section{Acknowledgements}

We greatly appreciate the funding provided by the United Soybean Board. Additionally, the corresponding author would like to thank all of the many individuals from the cooperating institutions for their hard work and dedication to this project.

\section{Literature Cited}

Ball DA (1992) Weed seedbank response to tillage, herbicides, and crop rotation sequence. Weed Sci 40:654-659

Baumhardt R, Lascano R (1996) Rain infiltration as affected by wheat residue amount and distribution in ridged tillage. Soil Sci Soc Am J 60:1908-1913

Beckie HJ (2006) Herbicide-resistant weeds: management tactics and practices. Weed Technol 20:793-814

Bell H, Norsworthy JK, Scott RC (2015) Integrating cereals and deep tillage with herbicide programs in glyphosate-and glufosinate-resistant soybean for glyphosate-resistant Palmer amaranth management. Weed Technol 30:85-98

Bensch CN, Horak MJ, Peterson D (2003) Interference of redroot pigweed (Amaranthus retroflexus), Palmer amaranth (A. palmeri), and common waterhemp (A. rudis) in soybean. Weed Sci 51:37-43

Blouin DC, Webster EP, Bond JA (2011) On the analysis of combined experiments. Weed Technol 25:165-169

Bradley KW (2013) Herbicide-resistance in the midwest: current status and impacts Weed Sci Soc Am Abstr 271

Bruce R, Langdale G, West L, Miller W (1992) Soil surface modification by biomass inputs affecting rainfall infiltration. Soil Sci Soc Am J 56:1614-1620

Carmer S, Nyquist W, Walker W (1989) Least significant differences for combined analyses of experiments with two-or three-factor treatment designs. Agron. J 81:665-672

Clements DR, Benoit DL, Murphy SD, Swanton CJ (1996) Tillage effects on weed seed return and seedbank composition. Weed Sci 44:314-322

Cousens R, Moss SR (1990) A model of the effects of cultivation on the vertical distribution of weed seeds within the soil. Weed Res 30:61-70

Craigmyle BD, Ellis JM, Bradley KW (2013) Influence of herbicide programs on weed management in soybean with resistance to glufosinate and 2, 4-D. Weed Technol 27:78-84

Culpepper AS, York AC, Batts RB, Jennings KM (2000) Weed management in glufosinate-and glyphosate-resistant soybean (Glycine max). Weed Technol 14:77-88

DeVore JD, Norsworthy JK, Brye KR (2013) Influence of deep tillage, a rye cover crop, and various soybean production systems on Palmer amaranth emergence in soybean. Weed Technol 27:263-270 
Dorado J, Del Monte J, Lopez-Fando C (1999) Weed seedbank response to crop rotation and tillage in semiarid agroecosystems. Weed Sci 47:67-73

Douglas A, Peltzer SC (2004) Managing herbicide resistant annual ryegrass (Lolium rigidum Gaud.) in no-till systems in Western Australia using occasional inversion ploughing. Pages 6-9 in Proceedings of the Fourteenth Australian Weed Conference. Wagga Wagga, New South Wales: Weed Society of New South Wales

Felix J, Owen MD (1999) Weed population dynamics in land removed from the conservation reserve program. Weed Sci 47:511-517

Fernandez-Cornejo J, Mcbride WD (2002) Adoption of Bioengineered Crops. Washington DC: US Department of Agriculture Economics Research Service, Agricultural Economic Report No. 810

Fernandex-Cornejo J, Wechsler SJ (2015) Adoption of Genetically Engineered Crops in the U.S. http://www.ers.usda.gov/ data-products/adoption-of-genetically-engineered-crops-in-theus/recent-trends-in-ge-adoption.aspx. Accessed September 1, 2015

Hager AG, Wax LM, Stoller EW, Bollero GA (2002) Common waterhemp (Amaranthus rudis) interference in soybean. Weed Sci 50:607-610

Heap I (2016) International Survey of Herbicide Resistant Weeds. www.weedscience.com/summary/home.aspx. Accessed January 2, 2016

Heisler C (1998) Influence of tillage and crop rotation on biological activity. Agribio Res 51:289-297

Hoffman ML, Owen MD, Buhler DD (1998) Effects of crop and weed management on density and vertical distribution of weed seeds in soil. Agron J 90:793-799

Kemper B, Derpsch R (1981) Results of studies made in 1978 and 1979 to control erosion by cover crops and no-tillage techniques in Parańa, Brazil. Soil Till Res 1:253-267

Krausz RF, Kapusta G, Matthews JL (1993) Soybean (Glycine $\max$ ) tolerance to 2, 4-D ester applied preplant. Weed Technol 7:906-910

Legleiter TR, Bradley KW, Massey RE (2009) Glyphosate-resistant waterhemp (Amaranthus rudis) control and economic returns with herbicide programs in soybean. Weed Technol 23:54-61

Legleiter TR, Johnson WG (2013) Palmer amaranth biology, identification, and management. West Lafayette, IN: Purdue Extension

Leon RG, Owen MDK (2006) Tillage systems and seed dormancy effects on common waterhemp (Amaranthus tuberculatus) seedling emergence. Weed Sci 54:1037-1044

Logan T, Baker J, Davidson J, Overcash M (1987) Effects of conservation tillage on groundwater quality: nitrates and pesticides. Chelsea, MI: Lewis Publishers. Pp 3-17

Mohler CL (1993) A model of the effects of tillage on emergence of weed seedlings. Ecol Appl 3:53-73

Morris N, Miller P, Orson J, Froud-Williams R (2010) The adoption of non-inversion tillage systems in the United Kingdom and the agronomic impact on soil, crops and the environment-A review. Soil Till Res 108:1-15

Mueller TC, Mitchell PD, Young BG, Culpepper AS (2005) Proactive versus reactive management of glyphosate-resistant or -tolerant weeds. Weed Technol 19:924-933
Neve P, Diggle A, Smith F, Powles S (2003) Simulating evolution of glyphosate resistance in Lolium rigidum II: past, present and future glyphosate use in Australian cropping. Weed Res 43:418-427

Neve P, Norsworthy JK, Smith KL, Zelaya IA (2011) Modeling glyphosate resistance management strategies for Palmer amaranth (Amaranthus palmeri) in cotton. Weed Technol 25:335-343

Nichols V, Verhulst N, Cox R, Govaerts B (2015) Weed dynamics and conservation agriculture principles: a review. Field Crops Res 183:56-68

Norsworthy JK, Griffith GM, Scott RC, Smith KL, Oliver LR (2008) Confirmation and control of glyphosate-resistant Palmer amaranth (Amaranthus palmeri) in Arkansas. Weed Technol 22:108-113

Norsworthy JK, Ward SM, Shaw DR, Llewellyn RS, Nichols RL, Webster TM, Bradley KW, Frisvold G, Powles SB, Burgos NR, Witt WW, Barrett M (2012) Reducing the risks of herbicide resistance: best management practices and recommendations. Weed Sci 60(Spec Issue):31-62

Pareja MR, Staniforth DW, Pareja GP (1985) Distribution of weed seed among soil structural units. Weed Sci 33:182-189

Powles SB (2008) Evolved glyphosate-resistant weeds around the world: lessons to be learnt. Pest Manag Sci 64:360-365

Reeves D (1997) The role of soil organic matter in maintaining soil quality in continuous cropping systems. Soil Till Res 43:131-167

Roberts H (1963) Studies on the weeds of vegetable crops: III. Effect of different primary cultivations on the weed seeds in the soil. J Ecol 51:83-95

Schultz JL, Myers DB, Bradley KW (2015a) Influence of soybean seeding rate, row spacing, and herbicide programs on the control of resistant waterhemp in glufosinate-resistant soybean. Weed Technol 29:169-176

Schultz JL, Weber M, Allen J, Bradley KW (2015b) Evaluation of weed management programs and response of FG72 soybean to HPPD-inhibiting herbicides. Weed Technol 29: 653-664

Shaw DR, Culpepper S, Owen M, Price A, Wilson R (2012) Herbicide-resistant weeds threaten soil conservation gains: finding a balance for soil and farm sustainability, Issue Paper 49. Ames, IA: CAST

Starica J, Burford P, Allmaras R, Nelson W (1990) Tracing the vertical distribution of simulated shattered seeds as related to tillage. Agron J 82:1131-1134

Swanton CJ, Shrestha A, Knezevic SZ, Roy RC, Ball-Coelho BR (2000) Influence of tillage type on vertical weed seedbank distribution in a sandy soil. Can J Plant Sci 80:455-457

Truman C, Reeves D, Shaw J, Motta A, Burmester C, Raper R, Schwab E (2003) Tillage impacts on soil property, runoff, and soil loss variations from a Rhodic Paleudult under simulated rainfall. J Soil Water Conserv 58:258-267

Webster TM, Cardina J, Norquay HM (1998) Tillage and seed depth effects on velvetleaf (Abutilon theophrasti) emergence. Weed Sci, 76-82

Webster TM, Nichols RL (2012) Changes in the prevalence of weed species in the major agronomic crops of the Southern United States: $1994 / 1995$ to 2008/2009. Weed Sci 60: $145-157$

Farmer et al.: Tillage effect on Amaranthus 
Yenish JP, Doll JD, Buhler DD (1992) Effects of tillage on vertical distribution and viability of weed seed in soil. Weed Sci 40:429-433

Young B (2006) Changes in herbicide use patterns and production practices resulting from glyphosate-resistant crops. Weed Technol 20:301-307
Received April 15, 2016, and approved August 25, 2016.

Associate Editor for this paper: Michael Walsh, University of Western Australia 